\title{
IDENTIFIKASI RISIKO DALAM PENGELOLAAN KEUANGAN DI BUMDES MASKUMAMBANG DESA KEMAMBANG KECAMATAN BANYUBIRU
}

\author{
Marisha Ayu Puspitasari \\ Fakultas Ekonomika dan Bisnis, Universitas Kristen Satya Wacana \\ Email : 232017095@student.uksw.edu
}

\begin{abstract}
Abstrak
Setiap aktivitas yang dilakukan oleh organisasi akan menimbulkan kemungkinan terjadinya risiko yang dapat berpengaruh dalam tercapainya tujuan dari sebuah organisasi. Risiko tersebut bisa berupa kecurangan maupun kesalahan yang tidak sengaja dan bisa menimbulka dampak yang kurang baik terhadap organisasi. Oleh sebab itu, tujuan penelitian ini adalah mengidentifikasi risiko dalam pengelolaan keuangan BUMDes Maskumambang Desa Kemambang Kecamatan Banyubiru dan mengusulkan mekanisme pengendalian untuk memitigasi risiko tersebut. Penelitian ini menggunakan data primer yang didapat dari wawancara online maupun offline serta terdapat beberapa dokumentasi mengenai pengelolaan keuangan di BUMDes Maskumambang. Penelitian ini merupakan penelitian kualitatif dengan teknik analisis menggunakan model Miles dan Huberman. Hasil Penelitian ini menunjukkan bahwa pengelolaan keuangan di BUMDes Makumambang masih bersifat sederhana sehingga terdapat beberapa risiko yang mungkin akan terjadi dalam aktivitas pengelolaan keuangan, selain itu pengendalian internal yang dilakukan oleh pihak BUMDes juga masih bersifat sederhana. Berdasarkan penelitian ini diharapkan bisa menjadi sarana evaluasi bagi pihak BUMDes Maskumambang, selain itu bisa dijadikan bahan kajian ilmu untuk menambah wawasan mengenai akuntansi desa dan penelitian ini juga bisa menjadi tambahan literatur untuk penelitian berikutnya terkhususnya dalam bidang akuntansi desa.
\end{abstract}

Keywords : Risiko, Pengendalian Internal, Pengelolaan Keuangan

\section{PENDAHULUAN}

Desa merupakan salah satu ujung tombak pembangunan di Indonesia karena desa menjadi sarana untuk peningkatan perekonomian masyarakat dan, pemberdayaan masyarakat. Akibatnya, desa dan pemerintah saling berkaitan (Noverman, 2018). Menurut Undang Undang Republik Indonesia Nomor 6 Tahun 2014 Tentang Desa, 2014, "Desa merupakan kesatuan masyarakat hukum yang memiliki batas wilayah yang berwenang untuk mengatur dan mengurus urusan pemerintahan, kepentingan masyarakat setempat berdasarkan prakarsa masyarakat, hak asal usul, dan/atau hak tradisional yang diakui dan dihormati dalam sistem pemerintahan Negara Kesatuan Republik Indonesia". Selain itu, Undang-Undang No 32 Tahun 2004 Tentang Pemerintah Daerah, 2004 pasal 21 menjelaskan mengenai pemberian hak otonomi daerah, untuk mengatur dan mengurus sendiri pemerintahan dan kepentingan dari masyarakat sesuai dengan peraturan yang telah dibuat dalam perundang undangan. Oleh sebab itu, desa dapat mengurus kebutuhan rumah tangga desa itu sendiri seperti mengelola badan usaha milik desa sesuai dengan potensi yang dimiliki oleh desa.

Kualitas pertumbuhan ekonomi desa seringkali menjadi masalah karena adanya ketimpangan antara perkembangan ekonomi desa dan kota (Mahmudah, 2018). Oleh karena itu, sesuai dengan Undang-Undang No 32 Tahun 2004 Tentang Pemerintah Daerah, 2004 desa diperbolehkan untuk mendirikan badan usaha yang disebut dengan Badan Usaha Milik Desa (BUMDes) sesuai dengan potensi desa yang ada untuk membangun perekonomian desa agar menjadi desa yang mandiri. Selain itu, pendirian BUMDes juga terdapat di Undang Undang Republik Indonesia Nomor 6 Tahun 2014 Tentang Desa, 2014 menjelaskan mengenai desa. BUMDes didirikan untuk menambah pendapatan desa sehingga desa dapat lebih maju lagi (Sutardi et al., 2017). Pemberdayaan BUMDes diharapkan 
dapat mencakup semua potensi yang dimiliki oleh desa dan mampu diolah serta dikembangkan oleh desa untuk kesejahteraan masyarakat. Oleh sebab itu BUMDes merupakan wadah untuk membantu pemerintah desa dalam memberdayakan dan memanfaatkan segala potensi yang dimiliki oleh desa dengan semaksimal mungkin.

Peraturan Menteri Desa, Pembangunan Daerah Tertinggal, Dan Transmigrasi Republik Indonesia Nomor 4 Tahun 2015 menjelaskan mengenai pendirian, pengurusan, pengelolaan dan pembubaran BUMDes. Pasal 12 dalam peraturan tersebut menyatakan bahwa BUMDes harus membuat laporan keuangan untuk dipertanggungjawabkan kepada para pemangku kepentingan. Oleh sebab itu, BUMDes perlu memiliki pengelolaan keuangan yang baik agar BUMDes dapat berjalan dengan efektif dan semakin berkembang agar BUMDes dapat menyusun laporan keuangan yang andal (Atikah et al., 2019). Akan tetapi, aktivitas BUMDes akan memiliki risiko yang dapat berdampak bagi kelangsungan usaha BUMDes. Oleh sebab itu, BUMDes perlu melakukan identifikasi risiko untuk dapat mengantisipasi dan meminimalkan risiko.

Model identifikasi risiko merupakan pemetaan sumber risiko yang mungkin dapat terjadi dan berpengaruh terhadap efektivitas dan efisiensi kinerja organisasi (Nasution et al., 2014) Identifikasi risiko diperlukan agar BUMDes dapat menentukan tingkat probabilitas risiko tersebut (tinggi atau rendah) sehingga BUMDes dapat melakukan perencanaan yang baik untuk melakukan pengendalian atas risiko itu.

BUMDes merupakan salah satu organisasi yang berperan penting dalam perkembangan ekonomi di Indonesia, sehingga di era Bapak Jokowi BUMDes sedang di gencarkan supaya dapat berkembang pesat. BUMDes juga dapat membantu masyarakat pedesaan sebagai wadah untuk meningkatkan perekonomian masyarakat sekitar. Namun tidak semua BUMDes dapat berjalan dengan lancar, terdapat beberapa masalah seperti kurangnya sumber daya manusia maupun pengelolaan keuangan yang kurang memadai hingga menyebabkan BUMDes tidak berhasil. Oleh sebab itu, identifikasi risiko merupakan salah satu hal yang penting bagi sebuah organisasi terkhususnya BUMDes, karena pihak BUMDes dapat mengetahui risiko yang mungkin akan terjadi dan seberapa besar pengaruhnya terhadap usaha BUMDes sehingga BUMDes dapat mengevaluasi aktivitas tersebut.

Salah satu BUMDes yang menarik diteliti adalah BUMDes Maskumambang yang berada di Desa Kemambang Kecamatan Banyubiru Kabupaten Semarang. BUMDes Maskumambang memiliki dua unit usaha yaitu penjualan kopi dan persewaan alat berat berupa molen. Pengelolaan keuangan BUMDes tersebut, selama ini masih sangat sederhana yang dapat menyebabkan terjadinya risiko yang bisa merugikan BUMDes, seperti tidak adanya pemisahan fungsi yang jelas yang merupakan salah satu bagian yang penting dalam suatu organisasi (Fajarsari et al., 2020). Hal itu dapat menyebabkan timbulnya risiko seperti adanya pencurian uang. Untuk itu, perlu dilakukan penelitian lebih dalam lagi agar dapat diketahui kemungkinan risiko yang dapat terjadi terkhususnya pada pengelolaan keuangan.

Penelitian tentang identifikasi risiko dalam pengelolaan keuangan BUMDes belum banyak dilakukan dan lebih berfokus pada pengelolaan keuangan BUMDes secara umum. Identifikasi risiko dan pengelolaan keuangan tidak dapat dipisahkan karena setiap aktivitas pasti mempunyai risiko, oleh sebab itu identifikasi risiko merupakan aktivitas yang penting dalam pengelolaan BUMDes. Identifikasi risiko dilakukan untuk menemukan hal-hal yang mungkin terjadi dalam BUMDes yang dapat mempengaruhi tercapainya tujuan.

BUMDes. Sebagai contoh, (Rofidah \& Rochayatun, 2020) meneliti tentang pengelolaan keuangan BUMDes Gondowangi dengan melihat prinsip kooperatif, partisipatif, emansipatif, transparan, akuntabel, dan sustainable. Hasil penelitian mereka menunjukkan bahwa pengelolaan keuangan di BUMDes Gondowangi masih bersifat sederhana. Penelitian lainnya dilakukan oleh Nurhazana \& Wahyuni (2020) meneliti tentang efektivitas pengelolaan keuangan dan akuntansi pada 
BUMDes. Hasil penelitian menjelaskan bahwa pengelolaan keuangan dan akuntansi dari BUMDes sangat berperan penting.

Berdasarkan penjelasan hasil penelitian sebelumnya yang lebih fokus pada implementasi pengelolaan keuangan di BUMDes seperti transparansi akuntabilitas dan efektivitas, penelitian ini lebih menekankan pada identifikasi risiko dari pengelolaan keuangan di BUMDes. Sehingga penelitian ini merumuskan persoalan penelitian sebagai berikut. Pertama, risiko apa yang ada dalam pengelolaan keuangan BUMDes Maskumambang Desa Kemambang Kecamatan Banyubiru? Kedua, pengendalian apa yang bisa memitigasi risiko tersebut? Penelitian ini bertujuan untuk mengidentifikasi risiko dalam pengelolaan keuangan BUMDes Maskumambang Desa Kemambang Kecamatan Banyubiru dan mengusulkan mekanisme pengendalian untuk memitigasi risiko tersebut. Penelitian ini diharapkan bisa menjadi sarana evaluasi bagi pihak BUMDes Maskumambang agar setiap risiko yang terjadi dalam BUMDes dapat diminimalisir dengan baik, selain itu untuk akademisi bisa dijadikan bahan kajian ilmu dan bisa menambah wawasan mengenai akuntansi desa. Penelitian ini juga bisa menjadi tambahan literatur untuk penelitian berikutnya terkhususnya dalam bidang akuntansi desa.

\section{KAJIAN PUSTAKA \\ Badan Usaha Milik Desa}

Keterlibatan masyarakat desa dan strategi diperlukan dalam membangun kawasan pedesaan. Pendirian BUMDes menjadi salah satu upaya untuk membangun dan memberdayakan kawasan pedesaan. Pendirian BUMDes didukung oleh pemerintah yang dibuktikan dengan ditetapkannya Peraturan Kementerian Desa, Pembangunan Daerah Tertinggal, dan Transmigrasi (KDPDTT) Nomor 4 Tahun 2015 . Pada peraturan tersebut menjelaskan bahwa setiap desa yang ada di Indonesia dapat mendirikan BUMDes untuk memakmurkan masyarakat sekitar. Selanjutnya, Peraturan Pemerintah Dalam Negeri Nomor 39 Tahun 2010 Tentang Badan Usaha Milik Desa menjelaskan bahwa BUMDes adalah usaha dari desa yang didirikan oleh pemerintah desa yang akan dikelola oleh masyarakat dan pemerintah desa.

BUMDes berfungsi untuk meningkatkan pendapatan asli desa dengan mengembangkan usaha ekonomi produktif agar terciptanya berbagai jenis usaha yang dapat dikelola untuk kesejahteraan masyarakat desa. Menurut Sutardi et al. (2017), BUMDes memiliki beberapa tujuan pokok seperti meningkatkan potensi yang ada di desa, meningkatkan perekonomian desa, mengembangkan pembangunan desa dan juga memberdayakan masyarakat sekitar agar lebih maju.

BUMDes memiliki unit unit usaha yang telah berbadan hukum. Unit unit ini yang akan dikembangkan agar bisa menjadi maju dan dapat memberikan dampak baik kepada masyarakat. Struktur kepengurusan BUMDes biasanya melibatkan tokoh masyarakat dan juga pegawai desa, hal tersebut berguna agar masyarakat dapat mengawasi secara langsung jalannya BUMDes tersebut.

Jumlah BUMDes yang ada di Indonesia sebanyak 35.000 dan hal tersebut sangat baik karena Rencana Pembangunan Jangka Menengah (RPJMN) 2014-2019 hanya menargetkan didirikannya 5.000 BUMDes. Meski demikian, BUMDes masih dihadapkan berbagai kendala yang membuat BUMDes tidak dapat berkembang optimal atau bahkan berhenti beroperasi. (Pradana \& Fitriyanti (2019) menunjukkan BUMDes di Kabupaten Tapin mengalami kesalahan dalam memilih usaha dan terlalu fokus dalam aktivitas infrastruktur, minimnya SDM yang terampil dalam mengelola BUMDes, dan minimnya pelatihan dan bimbingan terkait pengelolaan BUMDes. Selain itu, menurut Nursetiawan (2018) kurangnya partisipasi dari masyarakat dalam ikut serta mengelola BUMDes, dan pemerintah desa yang tidak maksimal dalam mengembangkan BUMDes menjadi kendala pengelolaan BUMDes. Selanjutnya, Agunggunanto \& Kushartono (2016) juga menjelaskan bahwa kendala yang dihadapi BUMDes di Kabupaten Jepara karena jenis usaha yang dikelola masih terbatas, minimnya SDM dan kurangnya partisipasi dari masyarakat. Selain itu, terdapat 2.188 BUMDes yang tidak beroperasi dan juga ada 1.570 BUMDes yang beroperasi namun tidak 
memberikan pendapatan bagi Desa (Anwar, 2019). Dari banyaknya permasalahan yang dihadapi oleh BUMDes disebabkan karena minimnya pengelolaan dari berbagai segi dan minimnya pengendalian internal sehingga banyak menimbulkan risiko-risiko yang mungkin terjadi.

\section{Risiko dan Pengendalian Internal}

Konsep pengendalian internal merupakan salah satu konsep yang paling terpenting dalam sebuah organisasi, karena dapat meminimalisir terjadinya risiko. Risiko ialah suatu konsekuensi yang bersifat negatif dan timbul karena adanya ketidakpastian dalam pengambilan keputusan (Firdayanti, 2012). Selain itu dijelaskan juga oleh Romney \& Steinbart (2011) bahwa risiko adalah peristiwa yang teridentifikasi yang dinilai dalam berbagai cara yang berbeda. Risiko perlu diidentifikasi dengan cermat agar tidak terjadi kesalahan yang dapat merugikan organisasi. Proses identifikasi risiko adalah proses yang secara sistematis dilakukan untuk memahami kemungkinan timbulnya risiko atau kerugian terhadap organisasi. Pada proses ini risiko yang ada atau mungkin terjadi akan diketahui dan diidentifikasi. Selanjutnya proses identifikasi risiko juga akan melihat bagaimana pengendalian internal yang telah dilakukan di suatu organisasi. Pengendalian internal diterapkan untuk menjamin bahwa tujuan perusahaan dapat tercapai seperti melindungi aset, memberikan informasi yang akurat dan andal, meningkatkan efisiensi operasional serta mendorong kepatuhan hukum maupun peraturan organisasi. Selain itu, pengendalian dibutuhkan oleh organisasi bukan hanya untuk melihat ancaman yang akan terjadi namun juga melihat dampak dan probabilitas dari ancaman tersebut (Romney \& Steinbart, 2011).

Definisi dari pengendalian internal telah dikemukakan oleh beberapa penulis atau lembaga, salah satunya yang dibuat oleh COSO (The Committee Of Sponsoring Organizations Of Treadway Commision) (Utami, 2018). Konsep pengendalian COSO menjadi konsep pengendalian yang modern. Terdapat lima komponen pengendalian dari COSO. Salah satu konsep yang akan dianalisis dalam penelitian ini yaitu risk assessment atau penaksiran risiko. Pengendalian ini digunakan untuk mengidentifikasi risiko risiko yang dapat terjadi dalam organisasi.

Dalam meminimalisir terjadinya risiko, pengendalian dibagi menjadi beberapa bagian yaitu: (1) preventive, adalah pengendalian yang diharapkan mampu untuk mencegah terjadinya risiko ; (2) detective, ialah pengendalian yang digunakan untuk memeriksa dan mencari tahu permasalahan yang dihadapi oleh sebuah organisasi ; (3) corrective, pengendalian yang berfungsi untuk mengatasi permasalahan yang terjadi dalam organisasi ; (4) compensating, yaitu pengendalian untuk memperkuat pengendalian yang sudah ada namun dirasa kurang efektif (Utami, 2018).

\section{Risiko dan Pengendalian Internal BUMDes}

Setiap aktivitas yang dijalankan oleh pihak BUMDes akan memiliki risiko. Oleh karena itu untuk menjaga BUMDes agar risiko-risiko tidak terjadi, dimana risiko tersebut dapat membahayakan unit usaha di bawahnya, maka dilakukan identifikasi dan analisis risiko. Hal tersebut bertujuan agar risiko dapat dikendalikan.

Penelitian Mandira et al. (2014) pada BUMDes Mandala Giri Amertha Desa Tajun mengungkapkan bahwa BUMDes tersebut sudah menunjukkan kualitas unsur-unsur pengendalian internal yang terdiri dari penaksiran risiko, informasi dan komunikasi, aktivitas dan lingkungan pengendalian serta pemantauan sudah berjalan efektif dan memadai. Namun sebaliknya, penelitian Widyawat et al. (2019) menunjukkan bahwa BUMDes memiliki beberapa kekurangan dalam mengelola pengendalian internal seperti membuat struktur organisasi yang jelas sesuai dengan tugas, keahlian,dan tanggung jawab pegawai, selain itu dengan melakukan pemeriksaan dan pemantauan secara berkala. Oleh karena itu belum semua BUMDes dapat menerapkan pengendalian internal yang baik dan efektif, sehingga perlu dilakukan perbaikan lagi agar tidak ada kesenjangan antar BUMDes di berbagai daerah. Pengendalian internal dikatakan baik apabila setiap aktivitas operasional 
BUMDes sudah berjalan efektif serta efisien, dapat diandalkannya laporan keuangan BUMDes, dan ketaatan pada peraturan yang berlaku (Mamuaja, 2016).

\section{METODE}

\section{Jenis Penelitian dan Teknik Pengumpulan Data}

Metode yang digunakan dalam penelitian ini adalah kualitatif deskriptif dengan menggunakan pendekatan studi kasus karena hanya meneliti satu BUMDes saja. Penelitian ini akan melakukan studi terhadap identifikasi risiko pengelolaan keuangan BUMDes yang terdapat di BUMDes Maskumambang Desa Kemambang, Kecamatan Banyubiru, Kabupaten Semarang. Selanjutnya penelitian ini berfokus pada identifikasi risiko pengelolaan keuangan untuk sub unit penjualan kopi BUMDes Maskumambang, karena kegiatan operasional sub unit penjualan kopi lebih kompleks daripada sub unit penyewaan mesin dan BPNT. Data yang digunakan dalam penelitian ini adalah data primer yang didapat dari wawancara secara langsung, wawancara dilakukan secara individual kepada setiap narasumber, selain itu terdapat beberapa dokumentasi mengenai pengelolaan keuangan di BUMDes Maskumambang. Data yang diperoleh akan mengacu pada proses identifikasi risiko menurut (Romney \& Steinbart, 2011).

Proses identifikasi risiko diawali dengan penetapan tujuan yaitu proses memahami visi dan misi BUMDes Maskumambang. Selanjutnya proses identifikasi kejadian mengidentifikasi peristiwa eksternal dan internal yang mempengaruhi implementasi strategi dalam mencapai tujuan yang telah ditetapkan dalam visi misi BUMDes. Tahap ketiga ialah penilaian risiko dan respon terhadap risiko. Penilaian risiko dilakukan dengan cara mengklasifikasikan risiko risiko yang mungkin terjadi pada peristiwa dalam mencapai tujuan BUMDes. Risiko akan diklasifikasikan menjadi risiko bawaan dan risiko residual. Setelah risiko-risiko yang mungkin terjadi diklasifikasikan, selanjutnya akan melihat respon BUMDes khususnya unit usaha penjualan kopi terhadap risiko risiko yang mungkin terjadi pada pengelolaan keuangan di unit tersebut.

Narasumber yang ada dalam penelitian ini adalah pihak pihak yang berhubungan dengan pengelolaan keuangan BUMDes yaitu penanggung jawab BUMDes Bapak Heru Susanto 48 tahun dan berperan sebagai Kepala Desa, kemudian pengurus sub unit penjualan kopi di BUMDes yaitu Bapak Giyono 42 tahun menjabat juga sebagai Kepala Desa Kemambang, selanjutnya bendahara BUMdes Bapak Rohmadi 38 tahun berperan juga sebagai Kepala Dusun Plalar, dan yang terakhir perwakilan dari masyarakat Desa Kemambang, Ibu Ani Sulistyaningsih 55 tahun dan Bapak Irfan Dwi 30 tahun. Penulis akan mengatur waktu dengan Kepala Desa supaya dapat melakukan wawancara kepada pihak pihak yang berkaitan, kemudian wawancara dilakukan pada tanggal $25-26$ Januari 2021. Pertanyaan dibuat sesuai dengan proses yang dilakukan dalam mengelola sub unit usaha penjualan kopi di BUMDes Maskumambang mulai dari pembelian, produksi hingga penjualan. Selanjutnya dari hasil pertanyaan wawancara yang diperoleh dari pihak narasumber akan dikembangkan sesuai dengan kebutuhan data dalam penelitian ini. Dokumentasi akan dilakukan sebagai bukti pendukung hasil wawancara, dokumentasi bisa berupa gambar misalnya foto maupun dokumen seperti laporan hasil pendapatan sub unit usaha penjualan kopi sebagai bukti informasi yang disampaikan oleh narasumber.

\section{Teknik Analisis Data}

Dalam penelitian ini, menggunakan teknik analisis data yang telah dijelaskan oleh (Miles \& Huberman (1992) bahwa analisis terdiri dari tiga kegiatan atau tahapan yaitu : reduksi data, penyajian data, dan penarikan kesimpulan, dikarenakan analisis data dilakukaan pada saat pengumpulan data itu berlangsung yaitu ketika wawancara dengan pihak BUMDes. Reduksi data adalah proses penyederhanaan atau pemilihan data dari berbagai informasi yang sudah didapatkan sesuai dengan kebutuhan yang diperlukan dalam penelitian ini. Langkah selanjutnya adalah penyajian data yaitu menyajikan semua data yang sudah dipilih berdasarkan kebutuhan yang dibuat dalam tabel yang 
nantinya berisikan risiko risiko yang mungkin dapat terjadi dalam setiap aktivitas yang berhubungan dengan pengelolaan sub unit usaha penjualan kopi di BUMDes Maskumambang. Data tersebut diperoleh dari wawancara yang telah dilakukan oleh penulis kepada pihak BUMDes, di dalam wawancara itu terdapat beberapa pertanyaan yang berkaitan dengan topik peneliti seperti visi misi yang dimiliki oleh BUMDes dan kendala apa saja yang dihadapi oleh pihak BUMDes terutama unit penjualan kopi. Tahap terakhir adalah penarikan kesimpulan yang dapat diartikan bahwa semua data yang sudah diperoleh dan sudah disajikan akan ditarik kesimpulannya dengan melihat pengendalian yang sudah diterapkan dalam BUMDes.

\section{HASIL DAN PEMBAHASAN \\ Risiko Pengelolaan Keuangan BUMDes Maskumambang}

BUMDes Maskumambang memiliki tujuan dalam menjalankan kegiatan usahanya. Tujuan tersebut yang akan digunakan sebagai patokan agar BUMDes berjalan sesuai yang diinginkan oleh para pemangku kepentingan. BUMDes Maskumambang dibentuk untuk menjadi wadah usaha yang memiliki potensi agar dapat dikembangkan dan dikelola oleh pemerintah desa dan masyarakat. Maksud didirikannya BUMDes Maskumambang supaya dapat meningkatkan taraf hidup masyarakat, dapat membantu percepatan pembangunan desa, salah satu sumber Pendapatan Asli Desa, dan menggerakkan perekonomian rakyat.

BUMDes Maskumambang memiliki aktivitas-aktivitas yang telah dilakukan guna menjalankan usahanya. Aktivitas tersebut ada dalam setiap siklus pada unit usahanya. Siklus bisnis dari penjualan kopi di BUMDes Maskumambang dimulai dari siklus pengeluaran kas, produksi, penggajian, penerimaan kas. Yang pertama siklus pengeluaran kas memiliki aktivitas pembelian bahan baku, pemasaran, dan pencatatan kas. Kemudian siklus produksi terdapat aktivitas mendesain produk dan operasi produksi. Selanjutnya di dalam siklus penggajian memiliki aktivitas kompensasi atau penggajian. Yang terakhir adalah siklus pengeluaran aktivitas, didalamnya mempunyai aktivitas penerimaan pesanan dan penerimaan kas.

Setiap organisasi memiliki siklus operasional ketika menjalankan aktivitas bisnis yang di dalamnya pasti terdapat suatu risiko dari setiap siklusnya. Risiko yang mungkin terjadi salah satunya adalah tindak kecurangan. Tindak kecurangan bertujuan untuk mengelabui orang lain demi memperkaya diri sendiri (Utami, 2018).

Siklus dimulai dari pengeluaran kas yang didalamnya terdapat aktivitas aktivitas terkait kas yang keluar. Yang pertama ialah aktivitas pembelian bahan baku. Bahan baku yang dibeli oleh pihak BUMDes adalah biji kopi mentah yang didapat dari kelompok tani di sekitar Desa Kemambang. Jenis kopi yang dibeli merupakan kopi robusta dengan harga 19.000 per kg. Setelah membeli biji kopi mentah, selanjutnya biji kopi tersebut dijadikan kopi bubuk dengan mesin roasting. Pengeluaran untuk jasa mesin roasting senilai Rp. 500.000. Kemudian untuk kemasan dari kopi yang akan dijual, pihak BUMDes membeli plastik seharga Rp. 500.000, stiker Rp. 200.000, dan sealer Rp. 160.000. Selanjutnya untuk pemasaran pihak BUMDes tidak mengeluarkan uang, karena pemasaran yang dilakukan hanya via online seperti instagram, facebook dan juga melalui orang per orang. Pengeluaran-pengeluaran tersebut digunakan keperluan unit usaha dalam jangka waktu satu bulan.

Pada saat ini belum terdapat tindak kecurangan yang terjadi di dalam BUMDes akan tetapi setiap aktivitas yang terjadi akan memiliki risiko yang mungkin terjadi (Heru Susanto, wawancara, 25 januari 2021). Risiko yang mungkin terjadi dalam pembelian bahan baku adalah kualitas bahan kopi terkadang tidak sesuai. Namun pihak BUMDes telah melakukan pengecekan kopi ketika akan membeli. Pengecekan kopi dilakukan oleh pihak BUMDes agar tidak mempengaruhi kualitas kopi yang dihasilkan oleh BUMDes. Oleh sebab itu risiko ini termasuk low dan dampak dari risiko ini juga low, karena dengan diadakannya pengecekan tersebut maka pihak BUMDes dapat meminimalisir risiko tersebut dan biaya untuk yang dikeluarkan untuk mengendalikan risiko itu juga kecil. Selain itu risiko bisnis yang dapat terjadi yaitu penyalahgunaan uang kas, karena tidak ada pemisahan fungsi 
antara yang mencatat dan menyimpan uang kas tersebut. Selain itu bisa juga terjadi manipulasi harga bahan baku karena tidak ada pengecekan kwitansi dalam penyerahan laporan bulanan. Ditambah lagi pihak BUMDes tidak memiliki anggaran hanya terdapat laporan sederhana seperti uang masuk dan keluar saja. Untuk meminimalisir adanya risiko-risiko tersebut, setiap bulan pihak BUMdes membuat laporan yang nantinya akan dipertanggung jawabkan kepada kepala desa untuk dicek. Laporan tersebut masih bersifat konvensional dan belum terkomputerisasi. Adanya kelemahan kelemahan tersebut membuat level risiko terjadinya kecurangan medium karena kas merupakan aktivitas yang paling rentan dan dampak dari risiko yang akan terjadi ialah medium. Hal tersebut disebabkan karena BUMDes Maskumambang terkhususnya unit penjualan kopi masih sangat terbatas dalam hal pendanaan. Oleh sebab itu jika terjadi kecurangan mengenai kas maka dampaknya akan cukup material bagi pihak BUMDes.

Aktivitas berikutnya ialah pemasaran, pemasaran yang dilakukan oleh pihak BUMDes masih cukup sederhana. Untuk menekan biaya yang akan dikeluarkan, pemasaran hanya dilakukan via instagram, facebook dan orang ke orang. Oleh sebab itu risiko menurunnya tingkat penjualan akibat pemasaran yang terbilang masih sederhana dapat mudah terjadi. Namun meskipun dengan pemasaran yang sederhana, hal tersebut dapat meminimalisir risiko diatas. Oleh karena itu risiko tersebut termasuk low dan dampak atas risiko itu juga low.

Siklus selanjutnya yaitu produksi, di dalam siklus produksi terdapat beberapa aktivitas seperti mendesain produk dan operasi produksi. Untuk menarik minat pelanggan maka diperlukan desain produk yang inovatif dan kreatif serta menyesuaikan dengan pangsa pasar yang berlaku. Kopi kemambang memiliki rasa yang enak dan berciri khas, kemasannya pun tidak kalah menarik meskipun masih sederhana namun sudah memiliki nilai tersendiri untuk menarik minat pelanggan. Namun kopi kemambang belum cukup terkenal dibanding kopi lain yang lebih ternama. Oleh sebab itu, perlu dilakukan pemasaran yang lebih luas lagi dan menambah informasi dalam desain produk mengenai keistimewaan kopi kemambang.

Risiko yang mungkin terjadi dalam aktivitas desain produk ialah pemilihan desain produk yang kurang tepat atau tidak sesuai dengan keinginan pasar, karena persaingan yang cukup ketat dan juga desain produk kopi kemambang yang masih sederhana. Hal tersebut dapat menyebabkan penjualan turun, yang akan berakibat pada terganggunya bisnis usaha kopi kemambang. Ditambah pada saat kondisi pandemi covid 19 seperti ini, kopi kemambang mengalami penurunan omset penjualan. Untuk mengatasi hal tersebut pihak BUMDes lebih giat dalam memasarkan kopinya via online maupun offline. Selain itu terdapat kerja sama ekspor yang akan dijalin oleh salah satu warga kemambang yang berada di luar negeri dengan BUMDes Kemambang. Level terjadinya risiko tersebut termasuk low karena desain produk kopi kemambang tidak terlalu berpengaruh pada menurunnya permintaan kopi. Begitu juga dampak dari risiko tersebut masuk kedalam kategori low.

Aktivitas selanjutnya dalam siklus produksi ialah operasi produksi. Pada penjualan kopi kemambang, kopi dibeli dalam bentuk biji mentah yang sudah disangrai dari kelompok tani kopi di Desa Kemambang. Kemudian untuk merubah menjadi kopi bubuk maka diperlukan mesin roasting kopi, mesin tersebut telah dimiliki BUMDes Maskumambang untuk kebutuhan BUMDes. Mesin itu diperoleh dari bantuan pemerintah provinsi. Setelah kopi menjadi bubuk, dimasukkan ke kemasan yang sudah disiapkan lalu di press dan siap untuk dijual. Varian kopi yang dijual ialah kopi robusta dan kopi lanang. kopi lanang merupakan kopi pilihan yang hanya ada satu biji dalam satu kerumunan kopi lain. Oleh sebab itu kopi lanang dijual dengan harga lebih mahal yaitu Rp. 15.000 dibandingkan harga kopi robusta yaitu $\mathrm{Rp} 12.000$.

Penyimpanan kopi yang telah dikemas dilakukan di etalase yang berada diluar kantor desa, sehingga dapat menyebabkan terjadinya risiko pencurian kopi. Pengendalian dari pihak BUMDes atas risiko tersebut dengan adanya CCTV yang dipasang di area pelataran BUMDes. Bentuk pengendalian lainnya ialah adanya pembatasan akses untuk pengambilan kopi karena etalase di kunci dan pemegang kunci ialah Bapak Topik selaku pengurus unit usaha kopi. Level risiko ini termasuk 
kedalam low karena adanya pengendalian tersebut maka kemungkinan risiko yang terjadi kecil. Selanjutnya dampak atas risiko yang dihasilkan juga termasuk dalam kategori low, sebab tidak terlalu berdampak yang cukup signifikan pada pihak BUMDes terkhususnya unit usaha penjualan kopi.

Selanjutnya ialah siklus penggajian. Para pengurus BUMDes terkhususnya unit usaha penjualan kopi diberikan upah sesuai dengan hasil dari penjualan kopi. Oleh sebab itu upah yang di dapat setiap bulannya tidak menetap. Pada siklus ini tidak ada pemisahan tugas antara yang mencatat gaji dan yang membawa uang gaji. Hanya satu orang yang bertugas untuk mencatat dan membawa uang yaitu bendahara BUMDes. Akibatnya risiko terjadinya kecurangan dalam memanipulasi uang gaji cukup tinggi dan dampak dari risiko tersebut juga tinggi karena apabila terjadi kecurangan maka akan berpengaruh pada sikap profesional dari para pengurus BUMDes.

Siklus yang terakhir merupakan siklus penerimaan kas. Kas diterima saat terjadinya transaksi pembelian dari pihak pembeli kepada BUMDes. Aktivitas ini merupakan aktivitas yang paling rentan adanya pencurian/penyalahgunaan kas, karena kas merupakan aset yang paling lancar sehingga sangat mudah sekali untuk diambil/disalahgunakan oleh orang yang tidak bertanggung jawab.

Setiap transaksi penjualan tidak disertakan dengan bukti transaksi misalnya seperti bukti nota penjualan. Hal ini dapat menyebabkan dilakukannya manipulasi dalam laporan yang akan dibuat, sehingga tidak dapat digunakan sebagai alat untuk mengevaluasi pencapaian kinerja yang telah dilakukan oleh BUMDes. Selain tidak dapat digunakan sebagai alat untuk mengevaluasi kinerja, transaksi yang dicatat tanpa bukti transaksi akan memberi kesempatan bagi pelaku kecurangan untuk memanipulasi pencatatan transaksi. Untuk mengendalikan risiko tersebut pihak BUMDes wajib membuat laporan terkait uang masuk dan keluar dalam kurun waktu satu bulan kemudian akan diserahkan kepada Kepala Desa di akhir bulan untuk di cek.

Pada unit usaha penjualan kopi juga tidak ada pemisahan fungsi tugas antara yang menerima kas masuk dan juga mengeluarkan kas sehingga semua yang terkait penjualan kopi hanya Bapak Topik yang mengurusnya. Tidak adanya pemisahan tugas menyebabkan kemungkinan kecurangan yang terjadi semakin besar dan mudah dilakukan. Akibatnya level risiko terjadinya kecurangan dalam aktivitas ini medium karena kas merupakan aktivitas paling rentan dan tidak ada pemisahan fungsi sehingga sangat mudah untuk melakukan tindak kecurangan ini. Dampak atas risiko ini ialah medium, karena BUMDes Mas Kumambang khususnya unit usaha penjualan kopi masih terbatas mengenai pendanaan sehingga akan cukup material jika terjadi kecurangan.

\section{SIMPULAN}

BUMDes Mas Kumambang terletak di Desa Kemambang, Banyubiru, Kabupaten Semarang yang dibentuk pada tahun 2018 berdasarkan Perdes Kemambang Nomor 004 tahun 2018. Salah satu unit usahanya yaitu penjualan kopi. Unit usaha kopi dalam siklus pengeluaran kas, produksi, penggajian dan penerimaan kas sudah menerapkan pengendalian internal namun belum dijalankan secara maksimal, meskipun sudah diterapkan pencatatan dan pembukuan atas transaksi pembelian dan penjualan kopi, pengecekkan bahan kopi, memasarkan via online maupun offline, mendesain produk dengan menarik, memasang CCTV, dan juga mereka sudah membuat laporan pertanggungjawaban yang diberikan kepada Kepala Desa di akhir bulan yang dapat digunakan sebagai evaluasi ke depan. Tetapi masih terdapat kekurangan yang ditemukan dalam pengendalian internal di BUMDes Mas Kumambang, yaitu pengendalian internal yang masih belum dapat dijalankan secara efektif karena terdapat terdapat permasalahan seperti tidak adanya otorisasi atau pemisahan tugas di unit tersebut karena hanya terdapat satu pengurus saja. Permasalahan lainnya adalah kadang dalam melakukan pencatatan atau pembukuan terhadap transaksi pembelian maupun penjualan pada aktivitas pencatatan yang tidak jarang dilakukan tanpa disertakannya bukti transaksi yang ada sehingga riskan untuk terjadinya fraud dalam pencatatan dan pembukuan. Permasalahan lain yang juga dialami BUMDes yaitu produk kopi yang dijual saat ini tidak memiliki pembeli tetap karena kurang dikenal di pasaran karena hanya dipasarkan lewat media sosial dan individu per 
individu saja. Selain itu, hal lain yang dihadapi BUMDes dalam penjualan kopi yaitu produk kopi yang sudah siap dijual hanya diletakkan pada etalase yang berada di luar kantor Desa Kemambang serta upah yang didapat pengurus BUMDes berdasarkan penjualan yang terjadi.

\section{IMPLIKASI DAN REKOMENDASI}

Sesuai dengan teori yang dijelaskan oleh Romney \& Steinbart (2011) bahwa risiko dan pengendalian internal merupakan salah satu aspek yang penting dan saling berkaitan bagi organisasi. Dilakukannya identifikasi risiko untuk mendorong BUMDes Maskumambang supaya berjalan efektif dalam menerapkan pengendalian atas risiko-risiko yang mungkin terjadi dalam setiap aktivitasnya. Selanjutnya bisa dijadikan dasar untuk menyusun rencana yang strategis untuk kedepannya supaya BUMDes dapat berkembang lebih pesat, serta membantu untuk mencapai tujuan dari BUMDes Maskumambang.

Hasil penelitian ini sebagai salah satu acuan yang digunakan bagi pihak BUMDes agar dapat meningkatkan manajemen risiko menjadi lebih baik lagi. Pengurus BUMDes dapat melihat apa saja kelemahan yang ada di dalam BUMDes Maskumambag, sehingga ketika terdapat ancaman yang hamper sama dapat mengerti bagaimana cara untuk mengatasinya.

\section{SARAN}

\section{Saran Teoritis}

Keterbatasan pada penelitian ini hanya menggunakan satu sub unit saja dalam identifikasi risiko, sehingga tidak dapat menilai bagaimana kinerja pihak BUMDes secara keseluruhan. Penelitian selanjutnya diharapkan untuk dapat mengidentifikasi risiko BUMDes secara keseluruhan.

\section{Saran Praktis}

Rekomendasi kedepannya kepada pihak BUMDes Mas Kumambang unit pengolahan kopi untuk menambah pengurus baru agar dapat melakukan pemisahan fungsi ataupun tugas. Dengan adanya pemisahan tugas diharapkan mampu meminimalisir risiko kecurangan dan juga aktivitas yang ada di BUMDes Mas Kumambang unit pengolahan kopi menjadi lebih efektif karena pembagian tugas ditujukan kepada pengurus yang ahli di bidang tersebut menghasilkan kinerja yang baik sehingga diharapkan akan berpengaruh juga terhadap tingkat kinerja BUMDes yang semakin membaik karena diterapkannya pemisahan tugas yang baik. Selain rekomendasi untuk melakukan pemisahan tugas, rekomendasi selanjutnya ialah menyimpan semua bukti transaksi yang ada, sehingga semua transaksi dan peristiwa yang dicatat ke pembukuan atau laporan dapat dipertanggungjawabkan kebenarannya, dan juga dengan adanya hal tersebut diharapkan mampu meminimalisir pencatatan transaksi fiktif. Bukti transaksi juga merupakan syarat sahnya pembayaran yang dilakukan oleh kedua belah pihak dalam dunia akuntansi. Bukti transaksi juga dapat digunakan sebagai alat koreksi ketika data keuangan diaudit dengan cara mencocokkan data-data transaksi yang ada. Selanjutnya pihak BUMDes lebih baik melakukan promosi-promosi langsung dan menjalin kerjasama dengan toko atau swalayan bukan hanya di daerah Banyubiru saja, melainkan keluar dari daerah tersebut seperti melakukan promosi dan menitipkan produk kopi tersebut untuk dijual di warung coffee shop atau minimarket di daerah Ambarawa, Bandungan dan sekitarnya.

\section{REFERENSI}

Agunggunanto, E. Y., \& Kushartono, E. W. (2016). Pengembangan Desa Mandiri Melalui Pengelolaan Badan Usaha Milik Desa (BUMDes). https://doi.org/https://doi.org/10.34001/jdeb.v13i1.395

Anwar, M. C. (2019). Jokowi geram! Ribuan BUMDes mangkrak. https://www.cnbcindonesia.com/news/20191211141345-4-122208/jokowi-geram-ribuanbumdes-mangkrak 
Atikah, S., Suhaedi, W., Rosyida, B., \& Rakhmawati, I. (2019). Pelatihan Pengelolaan Keuangan Badan Usaha Milik Desa Di Kabupaten Lombok Barat. Abdi Insani, 6(1), 113. https://doi.org/10.29303/abdiinsani.v6i1.181

Fajarsari, H., Djohan, H. A., Setiawan, A., \& Martini. (2020). Evaluasi Sistem Informasi Akuntansi Atas Penjualan Kredit PT. XYZ (Dealer Resmi Mitshubishi Cabang Semarang). Journal of Physics A: Mathematical and Theoretical. https://doi.org/10.1088/1751-8113/44/8/085201

Firdayanti, R. (2012). Persepsi Risiko Melakukan E-commerce Dengan Kepercayaan Konsumen dalam Mmebeli Produk Fashion Online. Journal of Social and Industrial Psychology, 1(1), $28-33$.

Peraturan KDPDTT Nomor 4 Tahun 2015 Tentang Pendirian, Pengurusan dan Pengelolaan, dan Pembubaran Badan Usaha Milik Desa, 1 (2015).

Mahmudah, S. (2018). Akuntabilitas laporan keuangan badan usaha milik desa (studi kasus: BUMDES Desa Sungon Legowo Bungah Gresik. Ecopreneur, 2(1), 52-56. https://doi.org/http://dx.doi.org/10.2345/e12.v1i2.376

Mamuaja, B. (2016). Analisis Efektivitas Penerapan Sistem Pengendalian Intern Terhadap Kinerja Instansi Pemerintah Di Dinas Pendapatan Kota Manado. Jurnal EMBA, 4(1), 165-171.

Mandira, R. G., Atmadja, A. T., \& Darmawan, N. A. S. (2014). Analisis Sistem Pengendalian Intern Pemberian Kredit Pada Badan Usaha Milik Desa (BUMDes ) MANDALA GIRI. 1(1). https://doi.org/http://dx.doi.org/10.23887/jimat.v2i1.4370

Peraturan Pemerintah Dalam Negri Nomor 39 Tahun 2010 Tentang Badan Usaha Milik Desa.

Peraturan Menteri Desa, Pembangunan Daerah Tertinggal, Dan Transmigrasi Republik Indonesia Nomor 4 Tahun 2015 tentang Pendirian, Pengurusan dan Pengelolaan, dan Pembubaran Badan Usaha Milik Desa, (2015). https://doi.org/10.1017/CBO9781107415324.004

Miles, M. B., \& Huberman, M. A. (1992). Qualitative Data Analysis (H. Salmon (ed.); 3rd ed.). SAGE Publications, Inc.

Nasution, S., Arkeman, Y., Soewardi, K., \& Djatna, T. (2014). Identifikasi Dan Evaluasi Risiko Menggunakan Fuzzy Fme Pada Rantai Pasok Agroindustri Udang. Indonesian Journal of Industrial Research, 8(2), 135-146.

Noverman, Y. (2018). Analisis Kesesuaian Pengelolaan Dana Desa dengan Peraturan Perundangundangan (Studi Kasus di Nagari Bukit Bual Kabupaten Sijunjung). JAKPP: Jurnal Analisis Kebijakan Dan Pelayanan Publik, 4(2), 68-81. https://doi.org/http://dx.doi.org/10.31947/jakpp.v4i2.5383

Nurhazana, N., \& Wahyuni, E. S. (2020). Efektivitas Pengelolaan Keuangan dan Akuntansi Pada Badan Usaha Milik Desa (BUMDes) Dengan Pendekatan Goal Model. Jurnal IAKP: Jurnal Inovasi Akuntansi Keuangan \& Perpajakan, 1(1), 41. https://doi.org/10.35314/iakp.v1i1.1421

Nursetiawan, I. (2018). Strategi Pengembangan Desa Mandiri Melalui Inovasi BUMDes. https://doi.org/http://dx.doi.org/10.25147/moderat.v4i2.1488

Pradana, H. A., \& Fitriyanti, S. (2019). Pemberdayaan dan Percepatan Perkembangan Badan Usaha Milik Desa (BUMDes) dalam Peningkatan Ekonomi Masyarakat dan Peningkatan Pendapatan Asli Desa. 14, 133-146.

Undang Undang Republik Indonesia Nomor 6 Tahun 2014 Tentang Desa, (2014).

Rofidah, N., \& Rochayatun, S. (2020). Implementasi Pengelolaan Keuangan Badan Usaha Milik Desa (Studi Desa Gondowangi Wagir Kabupaten Malang). 11(1), 60-70. https://doi.org/https://doi.org/10.18860/em.v11i1.7599 
Romney, M. B., \& Steinbart, P. J. (2011). Accounting information systems. In Information Technology and Innovation Trends in Organizations - ItAIS: The Italian Association for Information Systems. https://doi.org/10.4324/9781315629520-20

Sutardi, K. Y., Wahyuni, M. A., \& Sinarwati, N. K. (2017). Analisis kinerja keuangan badan usaha milik desa (bumdes) dalam proses penyaluran kredit desa Tajun tahun 2011-2015. JIMAT (Jurnal Ilmiah Mahasiswa Akuntansi) Undiksha, 8(2). https://doi.org/http://dx.doi.org/10.23887/jimat.v8i2.11311

Undang-Undang No 32 Tahun 2004 Tentang Pemerintah Daerah, Dpr 249 (2004). http://www.dpr.go.id/dokjdih/document/uu/33.pdf

Utami, I. (2018). Audit Internal: Pendekatan Kontemporer. In Akuntansi.

Widyawat, N. P. A., Sujaana, E., \& Yuniarta, G. A. (2019). Pengaruh Kompetensi Sumber Daya Manusia, Whistleblowing System. dan Sistem Pengendalian Internal Terhadap Pencegahan Fraud dalam Pengelolaan Dana BUMDes (Studi Empiris Pada Badan Usaha Milik Desa di Kabupaten Buleleng). 368-379. https://doi.org/http://dx.doi.org/10.23887/jimat.v10i3.2280 